\title{
Metas incertas de efluente de ETEs
}

Uncertain goals of WWTPs' effluent

Data de entrada:

22/09/2014

Data de aprovação: $01 / 04 / 2015$

Marcelo Kenji Miki (*) / Bruno Sidnei da Silva | Ana Lúcia Silva

DOI 10.4322/dae.2014.151

Resumo:

Muitos autores defendem que as legislações ambientais no Brasil são bastante avançadas quando comparadas às do restante do mundo, incluindo nesse conjunto a Resolução CONAMA n 357 , de 17 de março de 2005, e a Resolução CONAMA n 430, de 13 de maio de 2011, que dispõem sobre a classificação dos corpos de água e diretrizes ambientais para seu enquadramento, bem como as condições e padrões de lançamento de efluentes de ETEs em corpos receptores. No entanto, há uma série de inconsistências nesses dispositivos legais que levam a distorções em sua aplicação prática, principalmente quando o lançamento do efluente é proveniente de ETEs predominantemente domésticos. O primeiro questionamento refere-se ao caráter mandatório e não diretivo dessas legislações e, em segundo lugar, à falta do reconhecimento de que as tecnologias de tratamento de esgotos possuem limitações técnicas para o atendimento de determinados parâmetros. Por fim, essas inconsistências levam a uma falha sistêmica na questão ambiental relativa ao tratamento de esgotos, deixando em situação fragilizada não só os responsáveis pela operação das ETEs, como também os próprios agentes ambientais envolvidos nas atividades de licenciamento e fiscalização.

Palavras-chave: Legislação ambiental. Padrões de efluente. ETE.

\section{Abstract:}

Many authors argue that environmental regulations in Brazil are very advanced, including the CONAMA Resolution No. 357, 17/03/2005 and the Resolution No. 430, 13/05/2011, which deals with the standards for effluent discharge from WWTPs. However, there is a number of inconsistencies in these legal provisions which leads to distortions in their practical application, especially when the release of effluent comes from wastewater treatment plants. Our first issue refers to the mandatory and non-directive characters of those legal provisions. Secondly, the lack of recognition that technologies have technical limits to achieve certain parameters. Finally, these inconsistencies lead to a systemic failure in environmental issues concerning the processing of wastewater, leaving fragile situation not only responsible for the operation of sewage treatment plants, as well as their own environmental agents involved in the licensing and enforcement activities.

Keywords: Environmental regulation. Effluent standards. Wastewater treatment plants.

\section{Marcelo Kenji Miki (*)}

Engenheiro civil. Mestre pela Escola Politécnica da Universidade de São Paulo (USP).

Gerente do Departamento de Execução de Projetos de Pesquisa, Desenvolvimento e Inovação/TXE da Companhia de Saneamento Básico do Estado de São Paulo (Sabesp).

\section{Bruno Sidnei da Silva}

Engenheiro sanitarista e ambiental pela Universidade Federal de Santa Catarina (UFSC). Engenheiro sanitarista na Superintendência de Pesquisa, Desenvolvimento Tecnológico e Inovação da Sabesp.

\section{Ana Lúcia Silva}

Engenheira química pela Faculdade Oswaldo Cruz. Mestre em Engenharia Civil pela Escola Politécnica da USP. Doutora pela Faculdade de Saúde Pública da USP. Gerente de Divisão de Controle Sanitário do Médio Tietê/RMOC da Sabesp. 


\section{INTRODUÇÃO}

No Brasil, a situação do tratamento de esgoto não possui um quadro tão favorável quanto o de tratamento de água. De acordo com o Atlas de Saneamento de 2011, 44,8\% dos municípios brasileiros ainda não possuíam rede coletora de esgoto no ano de 2008.

Historicamente, um dos objetivos iniciais da coleta e afastamento do esgoto era a abordagem de saúde pública, de modo a preservar a população dos riscos à saúde pública, dos vetores e dos odores desagradáveis. Como a coleta do esgoto é feita em sua maior extensão por condutos livres, utilizando a força da gravidade, o destino final do efluente tratado nas estações é, na maioria das situações, um corpo de água.

É justamente nesse uso final do efluente tratado que reside a maior diferença em relação à água tratada para abastecimento público. Enquanto, para água tratada, há uma meta de qualidade muito clara de parâmetros a ser atingidos, para o esgoto tratado essas metas são estabelecidas caso a caso, de forma a proteger os diferentes usos da água (de acordo com as classes de enquadramento dos corpos de água superficiais), entre os quais, podem-se citar o abastecimento doméstico, a recreação de contato primário, a preservação de peixes e outros elementos da fauna/flora, a dessedentação de animais, a irrigação e a navegação.

Muitos autores argumentam que a legislação ambiental no Brasil é uma das mais avançadas do mundo, incluindo a Resolução CONAMA n 357 , de 17 de março de 2005, alterada e ampliada pela Resolução n 430 , de 13 de maio de 2011, denominadas daqui em diante, respectivamente, como RC 357 e RC 430. Essas resoluções dispõem sobre a classificação dos corpos de água e diretrizes ambientais para seu enquadramento, bem como estabelecem as condições e padrões de lançamento de efluentes e dão outras providências.
Uma das inovações da RC 357 foi a introdução do conceito de metas progressivas. Entretanto, entende-se que tanto a RC 357 quanto a RC 430 possuem ainda muitas lacunas, que serão discutidas neste texto e acarretam falhas de interpretação, provocando verdadeiras distorções do espírito original de preservação ambiental, levando a situações delicadas não só para a companhia de saneamento responsável pela operação da Estação de Tratamento de Efluentes (ETE), como também para o agente ambiental fiscalizador.

Pode-se alegar que todos esses problemas são fartamente discutidos e conhecidos no cotidiano do meio técnico, porém ressente-se de contribuições técnicas em artigos técnicos que de fato mostrem essas incongruências e não fiquem restritas a relatórios ou discussões de divulgação restrita.

\section{MODELO ATUAL DE IMPLANTAÇÃO E CONTROLE DE ETES}

No Brasil, o modelo regulador referente à operação de ETEs baseia-se em dois princípios:

a) padrões de lançamento do efluente final em corpo receptor: o processo de tratamento da ETE deve garantir certo nível mínimo de qualidade;

b) manutenção da qualidade do corpo receptor em função do lançamento do efluente final: o efluente final não pode alterar as condições de classe do corpo receptor.

Esses dois princípios são clássicos no controle de poluição das águas e, no Brasil, foram lançados inicialmente no estado de São Paulo, por meio do Decreto Estadual $n^{\circ} 8.468$, de 8 de setembro de 1976 - denominado daqui em diante como DE 8468 -, que serviu de fundamento para a regulamentação legal em nível nacional mediante a RC 357. Esse modelo regulador possui um amplo espectro e não restringe a sua abrangência a ETEs com recebimento de esgoto predominantemente 
doméstico, podendo, assim, subsidiar estudos de descarga de efluentes industriais, cada qual com poluentes mais característicos em função da matéria-prima utilizada.

A resolução também se baseia na classificação dos corpos de água do estado de São Paulo, regulamentada pelo Decreto Estadual n 10.755, de 22 de novembro de 1977. Um fato significativo desse decreto é o estabelecimento de classe 2 para todos os corpos de água, "exceto os alhures classificados".

Todo esse arcabouço legal da década de 1970 não apresentava caráter orientador, tampouco possuía o intuito de servir como diretriz para o estabelecimento de parâmetros. Assim, o lançamento de efluentes de ETEs deveria obedecer às condições, padrões e exigências preestabelecidos no campo teórico hipotético, ou seja, a abordagem desse modelo legal era mandatória e assim é até hoje, com a instituição da RC 357.

Para complementar esses instrumentos legais, a implementação desse modelo no Brasil foi realizada mediante o instrumento do Licenciamento Ambiental, com a emissão das seguintes licenças ambientais: prévia, instalação e operação.

Já nos Estados Unidos, um dos eventos mais significativos no campo do tratamento de esgoto ocorreu em 1972, por meio do Clean Water Act (CWA), Lei Pública 92-500 (METCALF; EDDY, 2014). O CWA não só estabeleceu metas e objetivos para restaurar e manter a integridade química, física e biológica das águas americanas, como também marcou uma mudança na filosofia do controle de poluição das águas. Por essa lei, ficou estabelecido o National Pollution Discharge Elimination System (NPDES) - Sistema Nacional de Eliminação de Descarga Poluidora -, que é um programa de autorização para cada lançamento de cargas poluidoras em corpo receptor, baseado em parâmetros mínimos tecnologicamente alcançáveis.
Nesse país, a aplicação das leis muitas vezes é amparada pela publicação de guias explicativos, de forma a tornar a interpretação mais clara e precisa, visto que a lei, por si só, não consegue abarcar a complexidade do mundo real. Como exemplo de guia explicativo de leis ambientais referentes ao saneamento, pode-se citar inicialmente o Permit writers' manual, direcionado aos agentes ambientais que estabelecem os padrões de emissão de efluentes das ETEs na fase de planejamento. Para realizar essa tarefa, o agente ambiental deve considerar, no estabelecimento dos limites, tanto a tecnologia disponível para tratar os poluentes quanto os limites que protegem os usos da água.

Outro clássico exemplo de guia explicativo é a publicação da Agência Ambiental dos Estados Unidos (EPA) referente ao uso agrícola de lodo, baseada na 40 CFR Part 503, A plain guide to the EPA Part 503 biosolids rule. Fora do contexto do saneamento, pode-se citar a Lei Americana de Práticas Corruptas Estrangeiras, cujo instrumento de apoio é a publicação $A$ resource guide to the U.S. foreign corrupt practices act, ilustrando, assim, uma abordagem diferenciada na aplicação da lei.

No Permit writers' manual, consta a definição de parâmetros mínimos a ser atendidos para tratamento secundário, proporcionando um embasamento para o dimensionamento, a operação e a fiscalização de ETEs (Tabela 1).

Tabela 1 - Parâmetros mínimos de tratamento secundário.

\begin{tabular}{|c|c|c|}
\hline Parâmetro & Média de 30 dias & Média de 7 dias \\
\hline DBO $_{5 \text { dias, } 20^{\circ} \mathrm{C}}$ & $30 \mathrm{mg} / \mathrm{L}$ & $45 \mathrm{mg} / \mathrm{L}$ \\
\hline $\mathrm{SST}$ & $30 \mathrm{mg} / \mathrm{L}$ & $45 \mathrm{mg} / \mathrm{L}$ \\
\hline $\mathrm{pH}$ & $6-9$ (instantânea) & - \\
\hline Remoção & $85 \%$ DBO e SST (1) & - \\
\hline
\end{tabular}

Fonte: EPA (1996).

Nota: (1) Sólidos em suspensão total. 
Essa abordagem de atendimento, considerando médias de 30 e sete dias, admite que medições pontuais possam ser excedidas num intervalo de tempo. A abordagem da RC 357 é diferente e apresenta um conceito em que os padrões de lançamento somente podem ser excedidos em situações excepcionais e desde que autorizados pelo órgão ambiental.

Quando a EPA propõe parâmetros mínimos por meio de médias num determinado intervalo de tempo, ocorre certa amarração entre o que é estabelecido na fase de projeto, pelos projetos básico e executivo da ETE, e na fase de operação, pelo plano de monitoramento dos efluentes. Dessa forma, não ocorrem incongruências, comumente encontradas no Brasil, entre o que é condicionado na licença prévia e na licença de operação. Como exemplo dessa incongruência, cita-se o novo texto da RC 430, que alterou parcialmente e ampliou as regras para lançamento de efluentes em corpos receptores.

Apesar de a RC 430 ter tratado o lançamento de efluente doméstico em uma seção exclusiva para esse tipo de efluente (o que é um avanço), possibilitou ao órgão ambiental a inclusão de outras condições e padrões de lançamento, constantes de uma tabela de parâmetros para efluentes em geral (ou seja, não domésticos), sem especificar a fase para aplicação dessas condições adicionais (planejamento ou operação da ETE). Assim, uma ETE projetada exclusivamente para tratar efluentes domésticos pode vir a ser cobrada durante sua operação a atender a padrões de determinados parâmetros para cujo processo de tratamento não foi desenhada, gerando para a atividade alto grau de insegurança jurídica.

O que se coloca em discussão é a necessidade de uma definição mais assertiva de parâmetros de projeto e controle operacional em ETEs, de forma a focar a gestão. Por exemplo, na RC 357, há uma série de parâmetros que definem a qualidade de um corpo receptor, mas que não deveriam ser objeto de preocupação para o monitoramento e o controle de uma ETE exclusivamente de esgoto doméstico, como, por exemplo, o bário. Afinal, normalmente não se projeta uma ETE para remoção de bário, mas, supondo que essa substância representasse um problema numa determinada bacia hidrográfica, seu controle deveria se refletir primariamente no estabelecimento de padrões de emissão numa etapa prévia de planejamento ou, ainda, num momento posterior, caso a ETE viesse a receber contribuição significativa dessa substância, por exemplo, em virtude de algum lançamento industrial autorizado.

Nessas situações, em que a preocupação com determinado parâmetro está associada ao lançamento de efluentes não domésticos na rede pública de coleta de esgotos domésticos, a ação do órgão ambiental deve ser preventiva e focada na fonte geradora desses poluentes. Como exemplo, a EPA estabelece padrões de lançamento de efluentes não domésticos na rede coletora para 21 categorias industriais, baseados na melhor tecnologia disponível e considerando seus efeitos no sistema de coleta e tratamento e na qualidade do efluente final da ETE.

De acordo com Sapia e Morita (2003), a identificação das concentrações limites está intimamente vinculada ao conhecimento prévio das contribuições estimadas de cada poluente, que somente podem ser determinadas a partir de um estudo regionalizado das fontes de efluentes não domésticos de uma bacia de esgotamento. Esse estudo regionalizado deveria também fazer parte da etapa de planejamento da ETE e ser realizado em parceria com o órgão ambiental. Nesse sentido, a EPA desenvolveu uma metodologia na qual os critérios relativos à operação e desempenho das ETEs foram convertidos em limites locais por meio de equações de balanço de massa. Esses limites locais foram calculados por poluente e para cada critério a ser considerado, levando em 
conta sua remoção nas várias unidades de tratamento. No cálculo dos limites para os poluentes conservativos, assumiu-se que a carga afluente ao processo de tratamento era igual à soma das cargas do efluente líquido e do lodo gerado no processo. Já no caso de poluentes não conservativos, os cálculos foram modificados para levar em conta as perdas por biodegradação, volatilização e adsorção no floco biológico. Para cada poluente, foram, então, calculadas várias concentrações limites admissíveis, derivadas dos diversos critérios adotados (qualidade da água, prevenção contra a inibição dos processos biológicos de tratamento, qualidade do lodo gerado), sendo a menor delas, isto é, a mais restritiva, selecionada como a máxima concentração admissível afluente à ETE. Se a concentração do poluente estivesse bem abaixo dela, estariam assegurados todos os critérios aplicáveis para o composto em questão. Assim, as cargas de poluentes originárias de fontes domésticas foram subtraídas da concentração máxima admissível, resultando numa máxima concentração industrial permitida, a ser distribuída aos diversos usuários do serviço público.

Portanto, ao se iniciar um projeto de ETE no Brasil, ressente-se de uma maior assertividade de parâmetros e, principalmente, de metas de qualidade de lançamento de efluentes domésticos, que em parte pode ser creditada à complexidade e obscuridade das leis atuais, bem como à ausência de guias explicativos.

$\mathrm{Na}$ fase de projeto de concepção de uma ETE, os parâmetros utilizados tradicionalmente no dimensionamento são:

- Demanda Bioquímica de Oxigênio (DBO) ou Demanda Química de Oxigênio (DQQO);

- $\mathrm{pH}$;

- sólidos em suspensão total;

- nitrogênio amoniacal;
- fósforo total;

- nitrogênio total;

- coliformes termotolerantes.

Portanto, são estes os parâmetros que deveriam ter, prioritariamente, metas estabelecidas na fase de planejamento, durante o requerimento de licença prévia junto ao órgão ambiental e, dessa forma, estabelecer as diretrizes técnicas para a elaboração de um projeto executivo de ETE. Ademais, a exemplo do que acontece nos Estados Unidos, seria altamente desejável que fosse estabelecido um plano de monitoramento para eles, interligando as metas de projeto com as metas operacionais.

\section{MANUTENÇÃO DO CORPO RECEPTOR}

$O$ estabelecimento de metas de lançamento de efluentes, visando à manutenção ou recuperação da qualidade do corpo receptor, é um instrumento que deveria ser primordialmente utilizado na fase de planejamento e concepção da ETE.

A manutenção da qualidade do corpo receptor como instrumento de controle e fiscalização de uma ETE pelo órgão ambiental não se mostra adequada, uma vez que seu padrão de qualidade depende de fatores bastante complexos e de contribuições difusas ao longo de toda a bacia hidrográfica. Como o que se opera é uma ETE e não uma bacia hidrográfica, a manutenção da qualidade do corpo receptor deveria ser utilizada como instrumento de monitoramento e não de controle, podendo a companhia operadora de um sistema de tratamento de esgotos contribuir nesse monitoramento, mas está além de sua atribuição a manutenção da sua qualidade, cuja gestão depende da ação conjunta de uma série de atores.

A implantação de uma ETE é uma atividade de capital intensivo e posteriores exigências de desempenho não previstas podem ser tornar extremamente custosas. Analisando seu ciclo de vida, nota-se a participação de diferentes atores desde a 
concepção até a operação, com constantes falhas de comunicação e, consequentemente, repetição de erros. Se, pelo lado da companhia de saneamento, notam-se essas falhas de comunicação desde a fase de projeto até a operação, por outro lado, também se podem inferir possíveis falhas de comunicação por parte do órgão ambiental, uma vez que o empreendimento percorre as fases de licenciamento prévio, de instalação e de operação.

Quando falta assertividade no estabelecimento de metas de efluentes, tem-se um verdadeiro menu de opções de parâmetro à disposição de qualquer cidadão para questionar o cumprimento da lei. Por exemplo, a RC 357 estabelece como padrões de manutenção do corpo receptor os parâmetros de densidade de cianobactérias e concentração de clorofila $A$, os quais, muitas vezes, são consequências da eutrofização, geralmente devido ao lançamento de nutrientes no corpo receptor. Esse tipo de preocupação deve-se, principalmente, aos efeitos no abastecimento público de água. A principal preocupação referente ao controle de cianobactérias e clorofila A no corpo receptor deveria recair no estabelecimento de padrão de lançamento para os nutrientes fósforo e nitrogênio no efluente da estação, visto que o afloramento de cianobactérias nos mananciais geralmente está associado a contribuições difusas na bacia, principalmente em regiões com expressivas atividades agrícolas.

Para ilustrar o que ocorre na prática, cita-se fato ocorrido em meados de 2013, quando a Companhia de Tecnologia de Saneamento Ambiental (Cetesb) lavrou um auto de infração referente ao desenquadramento do corpo receptor da ETE Sede de São Miguel Arcanjo, operada pela Companhia de Saneamento Básico do Estado de São Paulo (Sabesp), cujo processo de tratamento ocorre por meio de lagoas facultativas, devido ao alto teor de clorofila $\mathrm{A}$ e à densidade de cianobactérias no corpo receptor. Do ponto de vista meramente técnico, não faz muito sentido exigir parâmetros de clorofila A e cianobactérias para o controle de sistemas de lagoas de estabilização; no entanto, como está na lei e é mandatório, o agente ambiental se sente obrigado a cumprir o que está fielmente descrito na letra da lei.

Outra situação comum é quando a qualidade do corpo receptor se apresenta em condições limiares da conformidade. Nesse caso, qualquer lançamento adicional de efluente tratado no corpo receptor, mesmo que se tenham atingido os padrões de emissão na ETE, possui alto potencial de provocar seu desenquadramento, devido a uma condição desfavorável de diluição. Nessas situações, muitas agências ambientais acabam por autuar pontualmente a fonte causadora do desenquadramento, em vez de estabelecer um programa de recuperação da qualidade do manancial aplicável a todos os atores potencialmente poluidores da bacia, distorcendo a essência de enquadramento da própria RC 357.

Outro exemplo curioso diz respeito a uma cidade previamente desprovida de sistema de coleta e tratamento de esgotos, que passa a coletá-los e tratá-los gradativamente. Como geralmente o manancial encontra-se na fase inicial de operação, em desconformidade com os parâmetros estabelecidos para sua classe, devido ao lançamento in natura de esgoto doméstico, a ETE opera seguindo exclusivamente os padrões de emissão da RC 357 (e da RC 430) e é fiscalizada também exclusivamente em função desses padrões. Com o aumento progressivo da coleta e do tratamento de esgotos do município, o corpo receptor passa a apresentar melhorias em sua qualidade, ocasionando situações em que passa a se apresentar recuperado a montante do lançamento da ETE, mas ainda em desconformidade a jusante, devido à carga refratária lançada pela estação. Então, a ETE passa a ser autuada por crime ambiental, alegando-se alteração da qualidade do corpo receptor a jusante do lançamento. Em outras palavras, a ETE passa a ser autuada por ter contribuído pela melhoria da qualidade ambiental do corpo receptor. 
Por fim, uma situação um tanto confusa é quando o corpo receptor encontra-se desenquadrado naqueles parâmetros típicos utilizados no dimensionamento de processos. Caso se encontre na fase de concepção da ETE, não há um direcionador técnico explícito emitido pelo órgão ambiental para os estudos de autodepuração quanto às premissas a ser adotadas, como, por exemplo, os valores dos parâmetros da qualidade do corpo receptor na situação anterior à instalação da ETE. Já na fase de operação da ETE, é mais confortável a situação de desenquadramento a jusante do lançamento final de efluente para a companhia de saneamento, pois não se desenquadra o que já está desenquadrado.

\section{ENQUADRAMENTO DE CORPO RECEPTOR}

No estado de São Paulo, o enquadramento dos corpos de água foi realizado pelo Decreto Estadual $n^{\circ} 10.755 / 1977$, sendo que, desde essa publicação, muita coisa mudou no âmbito jurídico, como, por exemplo, a Lei Federal nº 9.433/1997, que institui a Política Nacional de Recursos Hídricos, e a própria RC 357.

O efeito prático desse enquadramento realizado há quase 40 anos é constatar a ocorrência disseminada de rios de classe 2 , o que é um tanto questionável devido ao uso. Como o Decreto Estadual $n^{\circ} 10.755 / 1977$ estabeleceu que todos os corpos receptores seriam de classe 2 , exceto os alhures classificados, infere-se que houve, por segurança e precaução, a inclusão de corpos de água nessa classe mais nobre. No entanto, ao priorizar uma classificação mais nobre, houve a classificação imediata de corpos de água de uso não tão nobre como classe 2, como aqueles destinados ao mero transporte de esgoto e corpos de água mais volumosos.

Uma maneira para solucionar tecnicamente a manutenção do corpo receptor é a execução de um emissário que possa despejar o esgoto tratado num corpo receptor com maior capacidade de diluição. 0 que se questiona é se, de fato, aquele corpo receptor de classe 2 corresponde ao uso preponderante atual ou mesmo desejável. A mera execução de emissários com o propósito de diluir esgotos tratados parece ser uma medida contraproducente num ambiente em que há escassez de recursos econômicos. O que torna a situação mais complicada é que, muitas vezes, é reivindicado pelas comunidades afetadas que a reclassificação de corpos de água adote, por obrigação, uma classe de corpo receptor mais restritiva do que permissiva. Essa visão, um tanto utópica, desconsidera o uso real do corpo de água e toma como verdade absoluta a rigorosidade com que foi realizada a classificação anterior. Outro contribuinte para o preconceito de um rio de classe 4 é fazer uma associação direta com os rios Pinheiros e Tietê, que são assim classificados, mas apresentam padrões fora dos limites desse enquadramento, pelo menos no trecho situado na Região Metropolitana de São Paulo.

Outra falha situacional é a ocorrência de padrões diferentes de classificação de corpos de água em nível estadual e federal, podendo-se cair no risco de interpretar arbitrariamente essas leis. Por exemplo, um rio de classe 4 , na legislação estadual paulista, possui águas destinadas ao abastecimento doméstico, após tratamento avançado, à navegação, à harmonia paisagística, ao abastecimento industrial, à irrigação ou a usos menos exigentes. Já na RC 357, destina-se à navegação e à harmonia paisagística. Na verdade, essas classificações de corpos de água não são equivalentes, uma vez que possuem diferentes valores de manutenção da qualidade.

Há quem entenda que a RC 357 não seria, de fato, tão impositiva, pois prevê mecanismos mais flexíveis, como as metas progressivas e o lançamento temporário de efluentes em caráter excepcional, mediante análise técnica fundamentada etc. Entretanto, para mostrar como, na prática, esses dispositivos teóricos são frágeis, basta se colocar 
no papel do agente ambiental. Ao fiscalizar uma ETE, bem como checar a manutenção de qualidade do corpo receptor, o agente ambiental fica submetido aos limites mandatórios, que podem ser pinçados por qualquer promotor do meio ambiente, para fazê-lo lavrar alguma autuação ambiental. Apesar da abertura teórica mencionada, o que de fato é considerado nas ações de fiscalização são os limites mandatórios. Além disso, se as metas progressivas são instrumentos que visam ao atendimento progressivo da qualidade do corpo receptor, questiona-se: por que não se estabelecem metas progressivas de tratamento durante a etapa de planejamento do empreendimento? Quando os compromissos futuros ficam muito abrangentes, o risco ambiental necessariamente cai, mas o risco como atividade econômica aumenta, visto que esta fica sujeita a atender a exigências muito restritivas no futuro. Esse tipo de abordagem inibe, principalmente, a iniciativa privada de assumir a prestação de serviços em ETEs.

Importa mencionar que as metas de qualidade do efluente não devem ser obrigatoriamente vinculadas à licença prévia. Elas podem e devem ser revistas, não de forma aleatória, mas, sim, programada e, de preferência, após um horizonte significativo da implantação da ETE ou, ainda, em situações em que ela começa a receber uma contribuição industrial, com poluentes específicos a ser monitorados. De certa forma, o que se questiona é: por que não inverter a ordem das exigências? Por que não estabelecer inicialmente diretrizes, para que, por meio de estudos técnicos, sejam fixados os padrões orientadores de lançamento por cada agência ambiental local?

\section{METAS DE NUTRIENTES EM ETES}

Para o estabelecimento de metas realistas a ser atingidas, devem-se saber, a priori, quais são as eficiências de remoção esperadas dos poluentes em cada tecnologia utilizada, principalmente no que diz respeito aos nutrientes.
Em termos históricos, a preocupação da remoção de nutrientes no tratamento de esgotos teve sua evolução no mundo com a própria história do tratamento de lodos ativados, cuja invenção é atribuída aos pesquisadores Lockett e Ardern, em 1914. Conforme Van Haandel e Marais (1999), nos anos 1950, introduziu-se a nitrificação como processo adicional ao da remoção do material orgânico nos sistemas de lodo ativado. Observouse que a nitrificação no sistema de lodo ativado era perfeitamente possível, mas era necessário aumentar a idade do lodo (diminuir a descarga de lodo de excesso). Isso se devia ao lento crescimento das bactérias responsáveis pela oxidação da amônia, que implicava a necessidade de um tempo de permanência longo dessas bactérias no reator biológico.

Na década de 1960, notou-se cada vez mais o crescimento do problema da eutrofização dos corpos de água receptores de esgotos tratados com grandes quantidades de nutrientes - notadamente, nitrogênio e fósforo. Tornou-se, assim, necessário desenvolver sistemas de tratamento terciário, isto é, sistemas que, além dos sólidos sedimentáveis (tratamento primário) e do material orgânico (tratamento secundário), pudessem remover os nutrientes (nitrogênio e fósforo). 0 nitrogênio é removido de forma biológica por processos sequenciais de nitrificação e desnitrificação. Na nitrificação, ocorre a oxidação biológica da amônia para nitrato, tendo-se o oxigênio como oxidante, enquanto, na desnitrificação, ocorre a redução biológica do nitrato para nitrogênio molecular, usando-se o material orgânico como redutor, em ambiente desprovido de oxigênio dissolvido. Já a remoção biológica de fósforo pode ser realizada por meio de descarga junto ao excesso de lodo. Normalmente, o lodo biológico contém em torno de $2,5 \%$ de fósforo. Sua remoção adicional é possível mediante a introdução de uma zona anaeróbia no reator biológico do sistema de lodo ativado. $O$ termo 'anaeróbio' significa que não há presença nem de oxigênio nem de nitrato. A ex- 
posição do lodo à condição anaeróbia e a passagem subsequente na zona aerada fazem com que se desenvolva uma massa de lodo rica em fósforo, sendo, assim, possível a remoção do fosfato da fase líquida. O fósforo acaba sendo descartado no lodo de excesso, que, nesse caso, tem um teor de fósforo muito maior que o lodo "normal".

Conforme USEPA (2007), a concentração de fósforo total no esgoto bruto ocorre em valores entre 6 e $8 \mathrm{mg} / \mathrm{L}$ e, após um tratamento secundário convencional, atinge valores entre 3 e $4 \mathrm{mg} / \mathrm{L}$. Já em sistemas com tratamento biológico aprimorado para remoção de fósforo, a concentração total atinge um valor de $0,3 \mathrm{mg} / \mathrm{L}$.

No Brasil, a questão da remoção de nutrientes em ETEs teve pouca evolução prática, com exceção de Brasília, que lança grande parte de seus efluentes em lagos. No estado de São Paulo, priorizou-se a transposição de esgoto em áreas de reservatórios para outras bacias, o que explicaria, em parte, por que no estado há poucas exigências na remoção de nutrientes em ETEs. Por outro lado, após a universalização do saneamento em muitos municípios desse estado, constata-se cada vez mais o questionamento acerca da melhoria da qualidade dos corpos hídricos, devido às condições de eutrofização em que se encontram ou por esses corpos receptores serem contribuintes de reservatórios eutrofizados.

A RC 357 estabelece, para ambientes lóticos e tributários intermediários, as seguintes concentrações de fósforo total: 0,1 mg/L para classes 1 e 2; e $0,15 \mathrm{mg} / \mathrm{L}$ para classe 3 . Essas exigências para manutenção do fósforo total no corpo receptor requerem razões de diluição da ordem de 20 a 40 vezes para efluentes de esgoto submetidos a tratamento secundário convencional. Considerando um tratamento terciário com baixa concentração de fósforo $(0,5 \mathrm{mg} / \mathrm{L})$, requer-se uma razão de diluição entre três e cinco, o que ainda pode ser muito exigente para locais com baixa disponibi- lidade hídrica. Em termos teóricos, nota-se que, para seguir à risca a legislação, se deve solicitar a remoção de fósforo para um universo maior de ETEs com tratamento secundário convencional, que lancem o efluente em rios de classes 1, 2 e 3, com exceção dos locais com grande razão de diluição. Já em rios de classe 4, destinados à navegação e harmonia paisagística, não há limite para manutenção de fósforo total.

Nos Estados Unidos, as exigências de fósforo total estabelecidas, conforme o NPDES, variam entre 0,10 e 1,0 mg/L e a exigência mais restritiva encontrada é de 0,05 mg/L (METCALF; EDDY, 2014). Já em termos operacionais, o nível mais baixo de fósforo encontrado de forma consistente em monitoramento de ETE é de $0,01 \mathrm{mg} / \mathrm{L}$, sendo a exigência legal estabelecida pelo NPDES de 0,2 mg/L (US EPA, 2007).

No estudo de remoção de nutrientes em ETEs desenvolvido pela EPA (2008), foram estabelecidos graus de tratamento conforme a classificação a seguir.

\section{Nitrogênio}

a) Efluente com alta concentração de nitrogênio: concentrações médias anuais acima de $5 \mathrm{mg} / \mathrm{L}$.

b) Efluente com média concentração de nitrogênio: concentrações médias anuais entre 3 e $5 \mathrm{mg} / \mathrm{L}$.

c) Efluente com baixa concentração de nitrogênio: concentrações médias anuais abaixo de $3 \mathrm{mg} / \mathrm{L}$.

\section{Fósforo}

a) Efluente com baixa concentração de fósforo: concentrações médias anuais entre $0,1 \mathrm{e}$ $0,5 \mathrm{mg} / \mathrm{L}$.

b) Efluente com concentração muito baixa de fósforo: concentrações médias abaixo de $0,1 \mathrm{mg} / \mathrm{L}$. 


\section{Remoção combinada de nitrogênio e fósforo}

a) Nitrogênio total maior que $5 \mathrm{mg} / \mathrm{L}$ e fósforo variável.

b) Nitrogênio total menor que $5 \mathrm{mg} / \mathrm{L}$ e fósforo total entre 0,1 e $0,5 \mathrm{mg} / \mathrm{L}$.

c) Nitrogênio total menor que $5 \mathrm{mg} / \mathrm{L}$ e fósforo total menor que $0,1 \mathrm{mg} / \mathrm{L}$.

O conhecimento desses parâmetros de emissão de nutrientes subsidia o agente ambiental no estabelecimento de metas realistas já na fase de planejamento, bem como direciona, numa etapa posterior, a questão de controle ambiental das metas a ser atingidas no efluente da ETE na fase de operação.

\section{DESINFECÇÃO FINAL DE EFLUENTE POR MEIO DE CLORAÇÃO}

Outro ponto questionado junto às agências ambientais é a exigência de cloro residual no efluente final na renovação de licença de operação das ETEs, principalmente aquelas localizadas em áreas litorâneas, onde há a necessidade de manutenção das condições de balneabilidade das praias, em vez de se avaliar a eficiência do processo de desinfecção mediante indicadores, como o grupo dos coliformes totais e coliformes termotolerantes, uma vez que há outras tecnologias de desinfecção, além da cloração.

No Brasil, a RC 357 e a RC 430 não definem níveis de cloro residual no efluente tratado, mas fixam limites dessa substância nas águas doces e salinas de classes 1 e 2 na ordem de 0,01 mg/L. Apesar da aparente nobre intenção do agente ambiental de fixar padrões de emissão mínimos de cloro residual no efluente final durante a emissão da licença ambiental de operação da ETE, visando a garantir os padrões de balneabilidade das praias, é importante destacar que, mesmo em baixas concentrações, o cloro residual livre ou combi- nado pode apresentar toxicidade para peixes e outros organismos aquáticos. Portanto, caso se deseje realmente fixar padrões de emissão para cloro, essa medida deve ser submetida a uma avaliação ecotoxicológica.

No estado de São Paulo, a Cetesb publicou, em 2013, a segunda edição do Manual de controle ecotoxicológico de efluentes líquidos. 0 manual enfatiza que os testes ecotoxicológicos possuem a peculiaridade de caracterizar os efluentes líquidos de forma mais abrangente, englobando todos os seus constituintes químicos, principalmente pelo fato de acusar a biodisponibilidade das substâncias presentes, bem como de detectar o efeito tóxico resultante das interações entre essas substâncias químicas. Ainda, ressalta que a avaliação do processo de julgamento do lançamento de efluentes líquidos em corpos receptores deve se basear no conhecimento do efluente como um todo, considerando tanto sua ecotoxicidade quanto sua diluição no corpo de água, evitando avaliar tais lançamentos baseados apenas na composição de cada agente químico isoladamente.

Este é outro exemplo característico da falha de comunicação entre os diversos setores envolvidos com o controle da poluição ambiental da própria agência ambiental, visto que a exigência de cloro residual no efluente final não tem considerado os efeitos toxicológicos adversos no ambiente aquático, indo contra os objetivos estabelecidos no seu Manual de controle ecotoxicológico de efluentes líquidos.

De acordo com a Environment Canada (2003), testes de toxicidade realizados na Califórnia demonstraram que o efluente de esgoto doméstico que havia sido clorado e desclorado (e que apresentava baixa concentração residual de sulfito) apresentou efeito menos tóxico para o ambiente aquático do que o efluente clorado e não clorado. Esses testes também indicaram que concentrações de íon sulfito $\left(\mathrm{SO}_{3}{ }^{-2}\right)$ abaixo de $10 \mathrm{mg} / \mathrm{L}$ 
não causariam efeitos tóxicos significativos para o ambiente aquático. Contudo, a dosagem excessiva de sulfito poderia exercer demanda de oxigênio e reduzir o oxigênio dissolvido no ponto de lançamento no corpo receptor. Apesar desse inconveniente, uma dosagem pouco acima da necessária de um agente desclorificante seria uma abordagem mais apropriada, uma vez que o monitoramento e controle de cloro residual no efluente são extremamente dificultados, principalmente em baixas concentrações. Ademais, estudos na Califórnia concluíram que concentrações de cloro residual na ordem de $0,02 \mathrm{mg} / \mathrm{L}$ afetam a biota aquática do corpo receptor.

Considerando apenas o critério de manutenção do padrão de cloro no corpo receptor, se a condicionante de cloro residual for mantida nas licenças de operação das ETEs, a concentração de 1 $\mathrm{mg} / \mathrm{L}$ de cloro residual no efluente tratado acarretará o não atendimento do padrão de qualidade da água no corpo receptor $(0,01 \mathrm{mg} / \mathrm{L}$ de cloro residual total) para todas as ETEs do litoral norte, visto que a razão de diluição do efluente nesses cursos de água teria de ser no mínimo 100 vezes maior que a vazão de descarte da ETE, além de causar efeitos tóxicos não mensurados à biota aquática do corpo receptor. A título de exemplo, se for mantida a concentração de cloro residual no efluente de $1 \mathrm{mg} / \mathrm{L}$, a ETE Indaiá, localizada no município de Caraguatatuba, cuja vazão média de tratamento é da ordem de $230 \mathrm{~L} / \mathrm{s}$, alterará o padrão de qualidade na mistura de seu efluente com o rio da Paca, cuja vazão mínima de estiagem é da ordem de $42 \mathrm{~L} / \mathrm{s}$, na ordem de oito vezes o padrão de qualidade desse manancial durante os períodos de estiagem.

Fica evidente, então, que em algumas situações a remoção de cloro residual (descloração) do efluente tratado antes do seu lançamento no corpo receptor pode ser necessária. Essa descloração é realizada por meio do emprego de um agente químico redutor ou por processos físicos de ad- sorção, como o carvão ativado. Alguns produtos químicos utilizados para redução do cloro residual a cloreto $\left(\mathrm{Cl}^{-}\right)$incluem o dióxido de enxofre $\left(\mathrm{SO}_{2}\right)$, sais de sulfito $\left(\mathrm{SO}_{3}\right.$ e $\left.\mathrm{S}_{2} \mathrm{O}_{5}\right)$, sulfito de sódio, bissulfito de sódio, peróxido de hidrogênio $\left(\mathrm{H}_{2} \mathrm{O}_{2}\right)$ e ácido ascórbico, sendo o dióxido de enxofre o agente químico mais amplamente utilizado para descloração de efluentes em grandes estações de tratamento. Sais de sulfito são geralmente empregados para pequenas estações, pois demandam menores requisitos de manuseio e segurança, quando comparados ao dióxido de enxofre. $A$ escolha do sal de sulfito é realizada com base na disponibilidade do produto no mercado e fatores econômicos, sendo o custo do produto geralmente em função do custo de transporte do material até a estação de tratamento.

A maior dificuldade encontrada no processo de descloração é controlar a dosagem do produto, principalmente quando se torna necessário atingir concentração de cloro residual próxima de zero no efluente. Levando em conta essa discussão da necessidade de descloração, caso seja feita a desinfecção do efluente final com cloro, é recomendável a realização de estudo técnico-econômico de viabilidade frente a outras tecnologias, como, por exemplo, a desinfecção com lâmpadas de radiação ultravioleta.

\section{CONCLUSÕES}

Esta nota técnica procurou fazer uma crítica à adoção do modelo legal vigente no estabelecimento de padrões de lançamento de efluentes no Brasil, trazendo alguns exemplos de distorções decorrentes da sua aplicação. Entende-se que o modelo atual traz uma série de lacunas que devem ser preenchidas, de forma a dar maior assertividade tanto para quem opera quanto para quem fiscaliza uma ETE, sendo a situação sempre mais frágil para quem está na ponta final, ou seja, na operação da ETE. Fazer correções de modo a polir ainda mais o efluente final após a implantação 
de uma ETE, normalmente, requer grandes investimentos e um prazo um tanto longo, justamente por ser uma atividade de capital intensivo.

Pode-se também citar que a situação em que se encontram as ETEs no Brasil ainda é muito deficiente, com diversos problemas não tratados aqui, como, por exemplo, projetos de engenharia deficientes, ausência de um plano sistemático de manutenção das instalações existentes, pressões para redução da mão de obra etc. A falta de assertividade no estabelecimento de metas de ETEs é apenas um pequeno exemplo do que ainda deve ser aperfeiçoado, de modo a contribuir na sua gestão efetiva.

Ao longo da discussão, várias das referências técnicas tinham como fonte a EPA, reconhecidamente habituada com os aspectos operacionais das ETEs nos Estados Unidos, incluindo as metas atingíveis de lançamento, bem como os custos operacionais envolvidos. Nota-se, então, que o envolvimento da EPA abrange, além das questões ambientais, o próprio cotidiano das ETEs, acerca de seus aspectos técnicos e econômicos. Esse tipo de postura, por si só, mostra uma abordagem totalmente diferente dos órgãos ambientais do Brasil, que preferem ficar à margem das discussões sobre a factibilidade ou não de um processo de tratamento de esgoto. Quando não há esse envolvimento, verifica-se a total despreocupação de se ter parâmetros ambientais realistas.

A imposição de parâmetros ambientais não realistas de lançamento de efluentes de ETEs só faz contribuir para o não cumprimento das leis, cuja responsabilidade recairia não somente sobre as companhias operadoras de saneamento, como também os próprios agentes ambientais, prejudicando toda a sociedade e o meio ambiente. Pelo fato de a RC 357 ser muito abrangente, invariavel- mente leva a uma perda de foco do que realmente deve ser controlado, sendo desejável que sua abordagem deixe de ser mandatória e passe a ser mais diretiva.

Não é intenção deste artigo fazer a proposição de uma nova legislação para controle de ETEs, pois entende-se que um novo modelo deve ser construído em conjunto com diferentes setores da sociedade. Foi dada especial ênfase a certos aspectos técnicos do tratamento de esgoto que podem ser extremamente triviais para determinado grupo de pessoas, mas que, na realidade, não se mostram tão óbvios para quem elabora as leis ambientais, devido às inconsistências práticas aqui discutidas e apresentadas.

\section{REFERÊNCIAS}

CETESB, Manual de Controle Ecotoxicológico de Efluentes Líquidos, $2^{\mathrm{a}}$ Edição, 2013.

ENVIRONMENT CANADA, Review of Municipal Wastewater Effluent Chrorination/Dechlorination Principles, Technologies and Practices, 2003

METCALF \& EDDY. Wastewater Engineering, Treatment and Resource Recovery. $5^{\mathrm{TH}}$ Edition, 2014.

NOYOLA ET AL. Typology of Municipal Wastewater Treatment Technologies in Latin America. Clean -Soil, Air, Water, 40(9), 926-932, DOI: 10.1002/clen.201100707, 2012.

SAPIA, P. M. A; MORITA, D. M. Critérios de recebimento de efluentes não domésticos em sistemas públicos de esgotos: uma análise crítica. Revista Engenharia Sanitária e Ambiental. Páginas 145-156. Vol. 8. 2003.

VAN HAANDEL, A; MARAIS, G. 0 comportamento do Sistema de lodo ativado, No ISBN 900 847. Campina Grande, PB. 1999

US EPA, Permit Writers' Manual, 1996.

US EPA, Advanced Treatment to Achieve Low Concentration of Phosphorus, 2007.

US EPA, Wastewater Technology Fact Sheet, Chlorine Disinfection, 1999

US EPA, Municipal Nutrient Removal Technologies Reference Document, EPA 832-F99-062, 2008 